\title{
Levy oration -2018 \\ Our industry through the eyes of a pasture agronomist
}

\author{
Cory MATTHEW \\ School of Agriculture and Environment, PN433 \\ Massey University, PB 11-222, Palmerston North 4442, New Zealand \\ c.matthew@massey.ac.nz
}

It's a great privilege and a career highlight to bring you this talk this morning, "Our industry through the eyes of a pasture agronomist." My talk is divided into 4 sections: (i) our heritage; (ii) the science of growing grass; (iii) ever present change; and (iv) thinking to the future.

The process of preparing my talk aroused my curiosity about the persona of Sir Bruce Levy. While reading his biography and publication list, the first point that impressed on me as an example to follow, was his drive. Sir Bruce was born in 1892 and left school at 14; his first employment was as a clerical cadet in the Department of Agriculture; he gained his BSc from Victoria University at the age of 36 , and eventually became director of the DSIR Grasslands Division in Palmerston North. One accolade described him as 'the evangelist of grassland farming'. A second point to impress was the diversity of publication topics ranging from ryegrass breeding through care of the bowling green, to investigation of feed flavour in butter. A third point of interest was the citation statistics for his 1933 article, The point method of pasture analysis. Web of Science records 316 citations, with 86 of those in the last 10 years. Levy is credited internationally with having invented the point analysis method of determining pasture species composition, now widely used in ecology research.

A second example for us to aspire towards is the lateral thinking in the design of New Zealand's 2017 America's cup boat. It was a preposterous idea to put cyclists on a boat, but the innovation delivered more power than the traditional 'grinders' and had some other hidden advantages. The rest is history. Such inventiveness has been a good part of the reason for the success of the New Zealand pastoral industries.

\section{Our heritage}

It was great to hear at the conference field day something of the local history of farming families in the McKenzie Basin. For my own family, the story starts when grandfather emigrated from Sunderland in the 1890s and purchased a block of bush on the Raglan Harbour, to carve out a farm. I still have the account ledger showing the cost of bush felling at 25 shillings per acre, paid in part by provision of meat and groceries to the bush-felling gang.

Around 1910, the family moved to Te Kuiti. The bill from Gunson's in Auckland for seed to sow the bush burn on the Te Kuiti farm was $£ 135$ for 2 tonnes of seed. My father served in Belgium in World War 1, and after the war developed the Te Kuiti farm for his nowwidowed mother. By the 1920s, the money the family

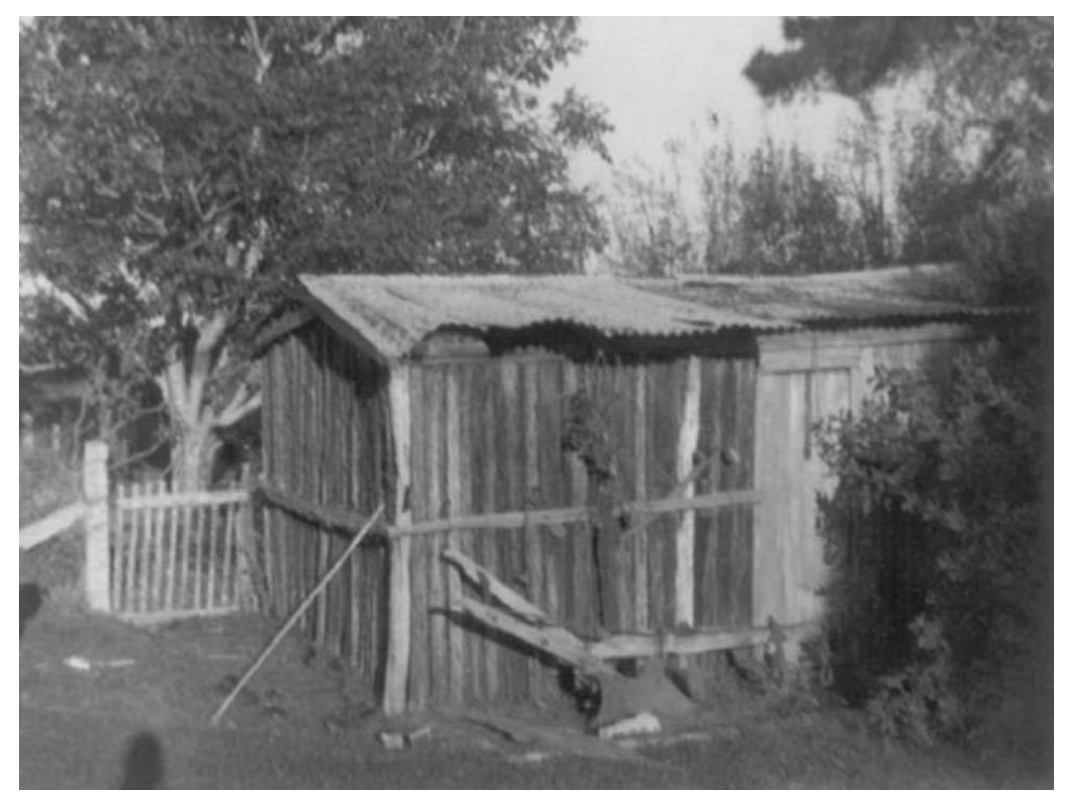

Figure 1 'The old whare' from which C. Matthew Snr managed (and eventually purchased) his mother's 165-ha sheep and beef farm west of Te Kuiti from c. 1920 to c. 1946. Note the horse-drawn plough in front, and rabbit traps hanging above with a hay knife wedged in the horizontal beam to the right of the traps. Photographed c. 1959. 
had brought from England had been spent. My father lived in a 20-foot x 12-foot whare he had built from punga logs from the bush and lined with felt. Cooking was in a camp oven over the open fire. Ploughing and haymaking were done with horses. During the great depression of the early 1930s, a bale of wool sent to auction in Auckland would not realise the cost of the rail freight, but a rabbit skin could fetch as much as sixpence. The rabbit traps that provided my Dad survival income during the slump were still hanging by the door of 'the old whare', as we used to call it, when I was a boy in the 1950s.

Stories like these are our heritage. We need to record them and pass them on. They make us who we are.

\section{The science of growing grass}

My career as a pasture agronomist has taught me that there is much more to know about the grass plant and grass swards than I could ever have envisaged, and in this section I need to be impossibly selective. I also want to acknowledge the $15 \mathrm{PhD}$ students I have supervised in my career, who have taught me so much.

The tiller density of a grass sward may range from 4,000 or less, to 20,000 or more per square metre, depending on the grass species and the grazing regime. This wide range more reflects alternative strategies for efficient light capture at different sward heights, than anything else. Dairy farm extension information in recent years has featured the 3-leaf structure of ryegrass tillers. When tillers in a sward attain their third leaf in a regrowth cycle, the sward is ready for grazing.

Successive leaves are borne on repeating segments called phytomers, and after a leaf has died the phytomer normally forms one or more roots. My own research has elucidated that the turnover cycle for the roots below ground parallels the one for leaves above ground. Older text books used to draw the tiller base like an onion or leek with roots more or less randomly radiating from the underside. Now, we draw a grass tiller base with nodes like a bamboo stem, and with roots at successive nodes. A ryegrass tiller axis typically has about 12 rootbearing phytomers, so the root turnover cycle takes about 4 times longer than the leaf turnover cycle. The young roots located close to the leaves are receiving enough photosynthate for active growth; by the $5^{\text {th }}$ phytomer from the leaves photosynthate consumption about equals supply; the older, larger roots, more distant from the leaves, are working in energy deficit and eventually die. The addition of root hairs adds about $10 \%$ to the root mass, but provides approximately 10x the absorptive surface of the branch roots that bear the root hairs. Considering that the root hairs (which provide most of the absorptive surface) are almost never studied, we really do not know very much about the root system yet.
A story less told, is that of the plant-water relationship. Plants are in a tug of war with dry soil in summer to extract water by osmotic suction for their growth. Our tools of trade for measuring this are the Scholander pressure chamber, which measures the pressure needed to force sap out of the cut end of a leaf (termed the leaf water potential), and the dew point psychrometer, which measures the osmotic potential of the plant sap. Our measurements show that ryegrass progressively increases its osmotic suction to values greater than 20 atmospheres in summer dry conditions; and in extreme cases can achieve greater than 35 atmospheres of osmotic suction for water extraction from soil. The sugars and other substances that provide this osmotic suction also appear to fuel regrowth when a drought breaks and the intense suction pressure is no longer needed because water is more freely available.

Lastly in this section, yield increase from plant breeding has been a stand-out observation over my career. When I was first employed at Massey University in 1984, the news of the day was that 'new' ryegrass cultivars Grasslands Nui and Ellett were yielding 10$20 \%$ more than the former 'flagship' cultivar Grasslands Ruanui that had served farmers well since the 1930s. A paper in the 1983 NZGA proceedings (Percival \& Duder 1983), reported 3-year yields for ryegrass trialled on pumice soil $30-\mathrm{km}$ northwest of Taupo, of 22.9 tonnes for Grasslands Ruanui and 26.1 and 26.0 tonnes for Grasslands Nui and Ellett, respectively. Over my career, Grasslands Nui has slipped down through the yield rankings as successive new cultivars have been released. Nowadays, Grasslands Nui is sometimes included in variety trials as a reference cultivar and, when included, typically sits among the lower yielding varieties in a trial. In the 2018 trial summaries of the New Zealand Plant Breeding and Research Association (NZPBRA; www.NZPBRA.org), Grasslands Nui, with a yield of 12.3 tonnes DM/ha/yr, is ranked $28^{\text {th }}$ among yields of 32 cultivar-endophyte combinations reported. The best 4 cultivars trialled exceeded 14.0 tonnes DM/ ha/year. It is interesting to note that for two cultivars tested with and without endophyte, the yield increase with endophyte present was about 1.5 tonnes $\mathrm{DM} / \mathrm{ha} /$ year. It is not only DM yield that has been improved by breeding effort. Some modern cultivars such as Agriseeds Bealey have notably high palatability, which assists farmers to achive high animal performance. The genetically modified high metabolisable energy (HME) ryegrass currently under devlopment by a team of AgResearch scientists is an outstanding achievement, but there is much work to do before HME varieties can come to market.

There are anecdotal farmer claims that modern ryegrass cultivars, while higher yielding in trials like those managed by NZPBRA, are less persistent on 
farm than older cultivars such as Grasslands Nui. Based on the evidence currently available to me, there is not a genetic problem with the persistence of modern ryegrass cultivars, compared to Grasslands Nui. Rather the modern cultivars are sown into a more stressful management environment, than Grasslands Nui used to be. In particular, summer stocking rates are increased when farmers graze stock off farm in winter, and negative impacts of summer moisture deficit on pasture are exacerbated by higher stocking rates.

\section{Ever present change}

One of the few things guaranteed in life is change. Major drivers of change include development of new technologies, financial realities such as movement in farm costs relative to farm prices, and access of products to markets. However, I felt this morning to review the issue of climate change. It would be interesting to know the opinions of this audience on that topic. For me as a spectator in various industry field days and conferences, it is common to hear views expressed that those calling for action on climate change are misinterpreting the available data.

The first point I would make is that atmospheric carbon dioxide $\left(\mathrm{CO}_{2}\right)$ concentrations are increasing, and the rate of increase is accelerating. When I was born in 1951, atmospheric $\mathrm{CO}_{2}$ levels were about 315 parts per million (ppm). When I started work at Massey University in 1984, the level was around $335 \mathrm{ppm}$. Today we have $410 \mathrm{ppm}$ atmospheric $\mathrm{CO}_{2}$. Today's atmospheric $\mathrm{CO}_{2}$ levels would have been regarded as a 'future climate change scenario' for plant growth experiments in the 1980s. In ancient geological times atmospheric $\mathrm{CO}_{2}$ levels were higher, but the present increase is certainly anthropogenic and breaks new ground in terms of recent geological times. Those not familiar with the data are urged to search and review the graph of continuous recordings from 1958 to the present, captured at the U.S. National Oceanic and Atmospheric Administration observatory on Moana Loa mountain in Hawaii.

Increased $\mathrm{CO}_{2}$ is predicted to reduce heat escape from the Earth into space and create a warming effect. The global mean temperature is currently about $1{ }^{\circ} \mathrm{C}$ warmer than it was 150 years ago, with notable movement in the last 30 years. Records of impacts such as glacier retreat, reduction in frost days, and a rising trend in mean annual temperature, are now commonplace in scientific records and publications from regions as diverse as New Zealand, The Tibetan Plateau in China, Central Europe, and the Arctic, among others. A very thought-provoking compilation of trends in global mean temperatures can be quickly accessed by an online search for "temperature spiral".

The world's weather and oceanic currents are convection engines that transfer heat from the equator, where a dispropoportionate amount of the sun's energy falls, to the poles, which would be much colder than they are now, if not for this heat transfer by convection. Increased heat entrapment arising from increased atmospheric $\mathrm{CO}_{2}$ (if real) implies an intuitive likelihood of more vigorous convection. We now have tools to understand the world's weather systems like never before. A real-time interactive view of world wind directions and speeds is now available at https:// earth.nullschool.net/. Next time we experience a 'polar blast' weather pattern, and you hear someone say 'that disproves climate change', check out the world wind map, and you will find that every cubic kilometre of air coming north in that weather event affecting New Zealand at that time, is being simultaneously replaced by southerly winds into the Antarctic from Africa or one of the oceans. In other words, when we experience a polar blast, the net effect is likely to be incremental warming of the Antarctic.

Does any of this affect New Zealand pastoral farmers? The emerging answer is, "yes". Recent Massey University PhD research by Janu Gobilik from Sabah shows that a trend to warmer drier summers in the lower North Island between 1980 and 2010 has reduced annual DM production on hill country farms by around $10 \%$. One case farm in the study had adopted a practice of grazing replacement hoggets off-farm through summer from November, to mitigate this emerging change in the seasonal pattern of pasture production.

\section{Thinking to the future}

Lateral thinking is needed to foresee and plan for eventualities that may become future issues for our industry. One of those is global exchange of 'virtual water'. Virtual water is the water used in the course of production of an item or commodity.

Take a litre of milk from the supermarket. At 7\% milk solids and $12 \mathrm{~kg}$ DM per $\mathrm{kg}$ milk solids, that is $0.84 \mathrm{~kg}$ DM. At 750 litres of water transpired by the grass sward while generating each kilogram of pasture DM, that is a virtual water cost of 630 litres, to produce that litre of milk from the supermarket. The urban public greatly underestimates the virtual water cost of producing the food they eat, and this is set to become an important issue in world trade.

My perception from 10 visits to China between 1996 and 2017 was that policy in China has shifted from a drive for food self-sufficiency in the 1990s to a current policy of tactical food imports to save water in China for other uses. This was readily confirmed in a literature search. A paper by Zhang et al. (2016) shows China's virtual water imports as rising from $\sim 50$ billion $\mathrm{m}^{3} /$ year in 2001-2002 to over 250 billion $\mathrm{m}^{3} /$ year in 2013 . The 
accompanying analysis states that China's virtual water imports rely too heavily on soya bean sourced from the USA, and need to be diversified. Meanwhile, irrigation to support soya bean production in the mid-west of the USA is depleting aquifer-derived fossil water at an unsustainable rate. That particular US-China trade relationship is unsustainable! In New Zealand, we need to position ourselves intelligently, within the context of global realities like this.

Another beyond-farm-gate issue of great importance to our industry is market access. This is largely handled for us by the Ministry for Primary Industries (MPI). Yet, in my preparation for this talk, the consultation processes between MPI and the farming industry that determine the foci and priorities for the MPI market access work on our behalf, were not so easy to discover. Perhaps we as an industry should be taking greater interest in matters like this? Certainly, progressive farmers are developing their own niche brands and export contacts, which indicates the opportunities available from entrepreneurial activity of this type.

In closing, an insight from my own research in collaboration with Chinese colleagues at Shanghai Jiao Tong University is that maintaining a truly 'clean-green' stance will be much more complex than we realised. One point that emerges from this Chinese research is that the cells of our bodies contain literally thousands of proteins all working in a delicately balanced way to complement each other and ensure that our immune defences and various other physiological processes function as they should. An imbalance somewhere in our 'proteome', as it is called, can send ripples through the whole system. That places a whole new perspective on the possible cause of chemical sensitivities in susceptible individuals. Other work in the same Shanghai laboratory shows that negative effects on earthworms of cadmium residues from fertiliser application are exacerbated by antibiotic residues at a level that might occur if poultry manure from treated birds were used as a fertiliser. Therefore, in planning the safe use of agrichemicals, we now need to be alert for possible synergies of side effect, between different chemicals. This points to one aspect of the future for environmental safety research.

In summary:

- We can all be proud of our industry heritage and contributions to this point in time;

- Going forward, science is indispensible and change inevitable;

- We have to 'work smart' across a broader range of knowledge and performance domains than ever before to stay in front.

\section{REFERENCES}

Percival NS, Duder FR. 1983. A comparison of perennial grasses under sheep grazing on the Central Plateau. Proceedings of the New Zealand Grassland Association 44: 81-90.

Zhang Y, Zhang J, Tang G, Chen M, Wang L. 2016. Virtual water flows in the international trade of agricultural products of China. Science of the Total Environment 557-558: 1-11.

The spoken version of this talk can be viewed online at:https://www.youtube.com/watch? $=\mathrm{ACamVg} 970 \mathrm{Us} \& \mathrm{t}=825 \mathrm{~s}$ The slides for this talk can be viewed online at: DOI: 10.13140/RG.2.2.16512.89608 